\title{
W poszukiwaniu siebie... Młodzież na drodze do samorealizacji
}

KEY WORDS

youth, self-realization, identity, life plans

\begin{abstract}
Słupska Kamila, W poszukiwaniu siebie... Młodzież na drodze do samorealizacji [Quest for Oneself... The Youth on the Way to SelfRealization]. Kultura - Społeczeństwo - Edukacja nr 2(10) 2016, Poznań 2016, pp. 201-213, Adam Mickiewicz University Press. ISSN 2300-0422. DOI 10.14746/kse.2016.10.16.

The article raises the issue of the young generation's striving for the realisation of its potential and talents as well as the use of development opportunities in the context of both favourable and unfavourable conditions of the social-cultural reality. The problems resulting from the axionormative chaos, differentiated opportunities, and changes in all of the areas of life that the contemporary youth wanting to appear on the societal arena is struggling with are also indicated in the article. The considerations oscillate around the categories of identity, needs, existential dilemmas and self-improvement as well as the goals and life plans of young people.
\end{abstract}

\section{Samorealizacja - kwestie wprowadzajace}

Istnieje wiele koncepcji samorealizacji, a jej problematyka podejmowana jest $\mathrm{w}$ zakresie filozofii (poszukiwanie istoty tego zjawiska, powiązanie $\mathrm{z}$ etyką), psychologii (określenie warunków, poszukiwanie czynników wyzwalających oraz hamujących ów proces, rozwijanie technik terapeutycznych, ułatwiających samorealizację), pedagogiki (samorealizacja jako jeden z celów edukacji, sytuacja bycia twórczym), antropologii kulturowej i socjologii (związki między rozwojem człowieka a rozwojem kultury) (Górniewicz, 1991; Jędrzejewski, 2013; Górniewicz, Rubacha, 1993). Samorealizacja jest jednym z wymiarów funkcjonowania jednostki w świecie obiektywnym. „Określa ona jakość i poziom dążeń człowieka do spełnienia potencjalnych zdolności $\mathrm{w}$ różnych obszarach własnej aktywności w zastanych warunkach materialnych i społecznych" (Górniewicz, Rubacha, 
1993: 7). W koncepcji Abrahama H. Maslowa traktuje się ją jako najwyższy motyw działania jednostki, jako potrzebę ludzką (Górniewicz, Rubacha, 1993: 34). W procesie dojrzewania biologicznego i psychicznego potrzeby ulegają wysublimowanemu rozwojowi. Potrzeby duchowe (wzrostu osobowości) nadbudowują się nad potrzebami podstawowymi (fizjologicznymi, bezpieczeństwa, afiliacji i miłości), podlegając sublimacji aż do zaistnienia potrzeby samorealizacji. Nie staje się to jednak nagle. Muszą zostać spełnione określone warunki (Górniewicz, Rubacha, 1993: 35). „Tylko zdrowy psychicznie, w pełni rozwinięty człowiek o dużym stopniu uspołecznienia, człowiek odpowiedzialny za siebie i inne osoby ma szansę na pełną samorealizację" (Górniewicz, Rubacha, 1993: 35). Wiesław Łukaszewski wskazuje na osobowościowe przesłanki samorealizacji, czyli: podmiotowość i tożsamość („Będąc wtopionym w otoczenie, człowiek nie może dostrzegać związków między nim samym a światem"), poczucie przynależności (do większych zbiorowisk ludzi, uwikłania w zdarzenia itd.), wrażliwość na różnice (napływających do jednostki informacji), tolerancja emocjonalnych konsekwencji rozbieżności, akceptacja siebie i świata, umiejscowienie kontroli („Szansę twórczego rozwoju osobowości mają ci przede wszystkim ludzie, którzy przeświadczeni są, iż sprawują faktyczną kontrolę nad samym sobą i własnymi zachowaniami, ludzie zdolni od uniezależnienia się od kontroli zewnętrznej"), przeświadczenie o wpływie na zdarzenia, zdolność do rozczłonkowywania i odraczania gratyfikacji, kryterialność (jednolity i względnie spójny system oceniania ludzi, zjawisk i różnych stanów rzeczy), poziom ogólności kategorii pojęciowych (Łukaszewski, 1984, s. 422-439). W psychologii i teologii uwypukla się również, w kontekście warunków samorealizacji, potrzebę sensu życia, który to wskazuje wartości będące drogowskazem dla człowieka, co wyraźnie podkreśla Victor Frankl (Górniewicz, Rubacha, 1993: 50), akcentujący konieczność wychodzenia poza siebie, samotranscendencję (Tylutki, 2014: 77). Można również zadać pytanie o przejawy samorealizacji. Na podstawie analizy literatury naukowej oraz badań empirycznych Józef Górniewicz i Krzysztof Rubacha wymieniają: prowadzenie aktywnego trybu życia, postawę twórczą, pozytywne emocje kierowane $\mathrm{w}$ stronę ludzi, siebie i ogólnie świata. To wszystko powoduje uzyskanie zadowolenia z życia. Psychologowie i filozofowie podkreślają, iż samorealizacja łączy się także z wartościami. „Występuje ona tylko wtedy, kiedy działania człowieka mają jednoznaczny wymiar pozytywny, kiedy można je dodatnio ocenić", a zatem kolejnym przejawem jest etyczność (Górniewicz, Rubacha, 1993: 53). Samorealizacja dokonuje się w świecie wartości, a jednocześnie jest procesem ich tworzenia ( $w$ wielu obszarach codziennej egzystencji - od rodzinnych po społeczne) (Jędrzejewski, 2013: 116).

Dlaczego zatem droga do samorealizacji nie zawsze jest łatwa? Ze względu na bariery utrudniające ten proces, a ich analiza odnosi się do trzech poziomów: 
czynników o charakterze globalnym (ustrój państwa, jego historia, struktura społeczna i mobilność społeczna), bytów społecznych, ponadjednostkowych (stosunki interpersonalne, kontakty społeczne), osobowości (Górniewicz, Rubacha, 1993: 80-81). I właśnie tym zagadnieniom poświęcony jest niniejszy artykuł, w którym autorka nie koncentruje się jednak na samej analizie wymienionych wyżej wyznaczników i koncepcji samorealizacji w powiązaniu z młodym pokoleniem, ale traktuje tę kategorię jako punkt odniesienia, służący przyjrzeniu się sytuacji młodzieży w kontekście konstruowania przez nią tożsamości (bowiem odpowiedź na pytanie: „kim jestem”? jest priorytetowa podczas „poszukiwania siebie”) oraz projektowania scenariusza własnego życia (determinowanego różnorodnymi czynnikami, wpływającymi na potencjalną i aktualną aktywność w rozmaitych dziedzinach życia - edukacja, praca zawodowa/przygotowanie do niej, sfera osobista).

\section{Tożsamość młodego człowieka - pytania o jej istotę w skomplikowanym świecie}

Poszukiwanie siebie niewątpliwie jest związane z realizacją zadań rozwojowych. Robert J. Havighurst, w odniesieniu do okresu dorastania, wskazuje na następujące zadania: ustanowić dojrzalsze relacje z rówieśnikami obojga płci, opanować rolę społeczną odpowiednią dla swojej płci, zaakceptować własne ciało i chronić organizm, osiągnąć niezależność emocjonalną od rodziców i innych dorosłych, zapewnić sobie niezależność ekonomiczną, przygotować się do zawodu, przygotować się do małżeństwa i życia rodzinnego, opanować sprawności intelektualne niezbędne do realizacji roli obywatela (Drwal, 1993: 17-18). Wszystkie one są komponentami głównego zadania, którego istotą jest ukształtowanie zintegrowanej tożsamości. W okresie adolescencji, zgodnie z koncepcją Erika Eriksona, kryzys to tożsamość kontra pomieszanie ról, gdzie właściwym rozwiązaniem jest poczucie siebie jako osoby (w przeciwieństwie do poczucia fragmentacji własnego "ja" i niejasnego poczucia siebie) (Zimbardo, 2004: 192). A zatem w wieku dorastania jednostka staje wobec wielu wyzwań tożsamościowych. Do klasycznego ich katalogu Piotr Oleś i Małgorzata Sobol-Kwapińska dodają jeszcze, wynikające ze specyfiki współczesności: określenie związku między rzeczywistością realną a wirtualną oraz podjęcie wiążących decyzji kształtujących przyszłość (Oleś, Sobol-Kwapińska, 2014: 19). Okres dorastania bywa burzliwy, obfituje w wiele napięć, $w$ mniejszym lub większym zakresie wpływających na funkcjonowanie zarówno młodzieży, jak i osób z jej otoczenia. Wydaje się, iż chaos i dezorientacja determinują właściwości tej fazy życia. A jednak, większości młodych udaje się, jak zaznacza Philip G. Zimbardo, „przejść do wieku dojrzałego bez nadmiernych 
cierpień” (Zimbardo, 2004: 197). Daniel Offer wraz z grupą współpracowników przeprowadził badania na populacji ponad 20 tysięcy młodych ludzi, pytając o ich osobiste doświadczenia. $\mathrm{Z}$ twierdzeniem „W normalnych okolicznościach czuję się odprężony” zgodziło się 91\% respondentów, następnie: „Cieszę się życiem” - 90\%, „Zwykle panuję nad sobą" - 90\%, „Czuję się silny i zdrowy” - 86\%, "Jestem zwykle szczęśliwy” - 85\%, „Nawet gdy jestem smutny, potrafię śmiać się z dobrego dowcipu" - 83\% (Zimbardo, 2004: 197). Jak zatem pogodzić te niezwykle optymistyczne wyniki z faktem wielu problemów, z jakimi zmagają się młodzi ludzie, którzy tym samym mają trudności z procesem samorealizacji? Ludwika Wojciechowska tłumaczy tę sprzeczność, odwołując się właśnie do zadań rozwojowych. Zgodnie $\mathrm{z}$ tą koncepcją - realizacja zadań stanowi zmienną wyjaśniającą zadowolenie jednostki, natomiast nieporadzenie sobie z nimi wiąże się z ostrą reakcją społeczeństwa, co prowadzi do stresu, zaniżenia samooceny, związanych z niesprostaniem wymaganiom. Wyniki badań, prowadzonych przez Autorkę (wśród grupy 100 gimnazjalistów), których celem było znalezienie odpowiedzi na pytanie o związek między stopniem realizacji zadań rozwojowych a poziomem dobrostanu osobowościowego, społecznego i emocjonalnego pokazały, iż istnieje duże prawdopodobieństwo, że młodzi ludzie, wypełniający odnoszące się do ich kategorii wiekowej zadania, mają większe szanse (niż osoby, które to zaniedbują) na osiągnięcie dobrostanu osobowościowego i społecznego ${ }^{1}$. Przejawy obniżonego poziomu tych dobrostanów to między innymi: poczucie braku akceptacji siebie, innych, wartości życiowych, poczucie bezsensu przy podejmowaniu działań, służących rozwojowi; przekonanie o braku wpływu na to, co się wokół dzieje i o wrogości czy też nieprzewidywalności świata, który niczego dobrego nie oferuje, przeświadczenie o braku integracji ze społeczeństwem, tradycją, kulturą. Te symptomy dowodzą o zagubieniu jednostki, o jej trudnościach z określeniem własnego miejsca i własnej roli i tym samym mogą skutkować przyjęciem przez nią pesymistycznej postawy wobec życia (Wojciechowska, 2011: 10 i n).

Zygmunt Bauman podkreśla: „Dzieło sztuki, które pragniemy uformować z kruchej materii życia, nazywa się tożsamością". Za każdym razem, gdy o niej mowa, „gdzieś w tle majaczy niewyraźny obraz harmonii, logiki i spójności, a więc tego wszystkiego, czego - ku naszej odwiecznej rozpaczy tak bardzo i tak dotkliwie brakuje w strumieniu naszych doznań" (Bauman, 2006: 128).

Obecnie żyjemy „,w świecie” $\mathrm{w}$ innym sensie niż wcześniej. Chociaż funkcjonujemy $\mathrm{w}$ środowiskach lokalnych, światy doświadczane u większości z nas są

\footnotetext{
${ }^{1}$ Związek między realizacją zadań rozwojowych a osiągnięciem przez młodego człowieka dobrostanu emocjonalnego okazał się słabszy (poziom dobrostanu emocjonalnego korelował dodatnio tylko z poziomem realizacji niektórych zadań rozwojowych).
} 
naprawdę globalne. A to niesie ze sobą liczne problemy na poziomie tożsamościowym. Dylematy odnoszą się do następujących dychotomii (opozycji): unifikacja - fragmentacja (nowoczesność dzieli i ujednolica, oddalone zdarzenia mogą być bliższe niż to, co dzieje się obok), bezsilność - kontrola (na przykład jednostka pokładająca zaufanie $\mathrm{w}$ innych lub w określonym systemie abstrakcyjnym, zazwyczaj jest świadoma, że nie ma na nie większego wpływu, a jednocześnie ta poczyniona inwestycja zaufania stwarza nowe możliwości), autorytet niepewność (brak niepodważalnych autorytetów, więcej niż wcześniej źródeł pretendujących do ich rangi), doświadczenie osobiste - doświadczenie urynkowione (nowe perspektywy, ale standardowe efekty, znaczenie konsumpcji coraz to nowszych dóbr ${ }^{2}$, także ryzyko „opakowania i rozprowadzania zgodnie z zasadami rynku" samorealizacji) (Giddens, 2010: 251-268). Współczesny człowiek, co podkreśla Zbyszko Melosik, żyje w dwóch rzeczywistościach, a zatem w jego tożsamość wpisana jest sprzeczność. Oczekiwanie racjonalności i dyscypliny zderza się z dużą swobodą dyktowaną przez sferę popkultury i konsumpcji (rygoryzm versus rozluźnienie, tożsamość konformistyczna wobec reguł versus rozproszenie i niejednoznaczność tożsamości). Triumf codzienności wygrywa $\mathrm{z}$ wielkimi ideałami. Pytania o sens nie mają głębi egzystencjalnej, są raczej pytaniami o zadowolenie $\mathrm{z}$ chwili. "Kategoria kontemplacji zastąpiona została przez kategorię «od-razowości»". Tożsamość przypomina kostkę Rubika, choć różni się od niej ciągłą zmianą elementów (Melosik, 2015: 13-25). Aktualne pozostaje również pytanie: Jak połączyć poczucie anonimowości (związane z uniformizacją i masowością) z pragnieniem uczynienia własnego życia niepowtarzalnym? (Oleszkowicz, 1995: 64). A jednocześnie to właśnie w okresie młodości i wczesnej dorosłości problemy związane z sensem życia nabierają szczególnego znaczenia. Wówczas są powiązane, jak podkreślają Marzena Dekiel, Alina Ukalisz i Katarzyna Wiak, wskazując na wiek 17-22 lata, $\mathrm{z}$ „myśleniem abstrakcyjnym, z osiągniętą wiedzą, ale i samorealizacją, samowartościowaniem i w tym kontekście wartościowaniem wszystkiego i wszystkich". Badania prowadzone przez Autorki pokazują, iż poziom doświadczanego sensu życia oraz motywacji do jego nadawania i określania celu różni się, jeśli chodzi o młodzież pochodzącą z miasta i wywodzącą się z terenów wiejskich. Ta pierwsza wykazuje tu większą dojrzałość (między innymi poprzez wyższy poziom samoświadomości i zdolność określenia własnej tożsamości, większe umiejętności w zakresie sterowania swoim życiem, poczucie ukierunkowania w czasie z przeszłości ku przyszłości). Młodzi pocho-

\footnotetext{
${ }^{2}$ „W świecie, w którym rozmyślnie nietrwałe przedmioty stanowią budulec tożsamości - także z konieczności nietrwałych - trzeba zachowywać nieustanną czujność, ale przede wszystkim trzeba dbać o elastyczność i pielęgnować umiejętność szybkiego przystosowywania się do nowych warunków, aby nadążać za zmieniającym się kształtem «zewnętrznego» świata”. Bauman, 2006: 132.
} 
dzący ze środowiska wiejskiego natomiast są bardziej niepewni, mają większe trudności z „dostrzeżeniem kierunku swojego istnienia”, co Autorki tłumaczą mniej sprzyjającymi warunkami do osiągania celów związanych $\mathrm{z}$ ich egzystencją, "pomimo że zaistniałe $w$ ostatnich latach przemiany ustrojowe pobudziły aspiracje edukacyjne i życiowe na dużą skalę" (Dekiel, Ukalisz, Wiak, 2013: 172-178).

Ciekawym aspektem rozważań na temat kwestii związanych z tożsamością jest przyjrzenie się dyskursowi tożsamościowemu młodzieży. Badania w tym zakresie prowadziła Dorota Konieczna. W ich ramach, koncentrując się na językowej stronie zagadnienia, przeanalizowała opinie, głosy wyrażone przez młodych ludzi urodzonych po 1989 roku, poszukując między innymi odpowiedzi na pytanie: czy ten dyskurs jest jednorodny i co wpływa na jego realizację? Analiza wypowiedzi pozwoliła na wyróżnienie czterech realizacji dyskursu oraz ich wariantów:

[1] relatywistyczny dyskurs tożsamościowy - dla tych respondentów nie istnieje żadna zasada, według której wybieraliby istotne dla siebie wartości (dwa warianty: globalnego nastolatka ${ }^{3}$ i wariant plastyczny ${ }^{4}$ - inne rozumienie zmienności, która powiązana jest $\mathrm{z}$ ważnymi wydarzeniami w życiu, wyeksponowane inne wartości);

[2] dyskurs przejściowy ${ }^{5}$ - świadomość, iż zmienność jest koniecznością, ale jednak tęsknota za stabilnością;

[3] stabilizujący dyskurs przejściowy - „zdecydowana deklaracja dotycząca albo istnienia zasady rządzącej doborem wartości, albo, mimo nieistnienia zasady, niezmienności wartości” (dwa warianty: tradycyjny ${ }^{6}$ - deklaracja, iż wartości nie będą ulegały modyfikacji, ale nie ma zasady, na podstawie której badani za ważne uznali właśnie te wartości, i wariant rodzinny $^{7}$ - deklaracja o istnieniu zasady rządzącej doborem wartości, a także dopuszczana możliwość ich zmiany);

\footnotetext{
${ }^{3}$ Plany na przyszłość są zróżnicowane, niepowtarzalne, oryginalne, cechy charakterystyczne to: dynamizm i wiara we własne siły.

${ }^{4}$ Wybór wartości jest mniej jednoznaczny niż w przypadku globalnych nastolatków, wskazujących na dwa ich typy: wartości moralne (dobierane ze względu na dobro drugiego człowieka) i odczuciowe (kontekst osobisty). Tu natomiast, wśród istotnych znalazły się wartości: moralne, odczuciowe, witalne i poznawcze.

${ }^{5}$ Jest to najbardziej uniwersalny sposób mówienia o tożsamości młodych ludzi (zamieszkujących różne środowiska).

${ }^{6}$ Plany na przyszłość są z reguły niezwykle pragmatyczne. „Ich realizacja wychodzi od obecnej sytuacji życiowej (chcę zdać maturę, dostać się na studia, ukończyć studia), by później skupić się przede wszystkim na własnej rodzinie (którą większość respondentów chce założyć) i pracy zawodowej (często jakiejkolwiek, bo sytuacja gospodarcza w Polsce nie jest najlepsza). Konieczna, 2014: 142.

${ }^{7}$ Zmiana, choć niewykluczona, jest raczej niepożądana.
} 
[4] stały dyskurs tożsamościowy ${ }^{8}$ - przekonanie o „niewzruszalności zasad i wartości, które są dla respondentów najważniejsze" (Konieczna, 2014: 142).

Poczynione analizy umożliwiają spojrzenie na młodego człowieka z perspektywy jego opowieści o sobie, pozwalając wyodrębnić pewne elementy wspólne, ale też wskazać niejednorodność dyskursu, poprzez odwoływanie się do kategorii istotnych także z pedagogicznego punktu widzenia.

Co składa się zatem obecnie na system aksjonormatywny? Czy dzisiejsze ustalenia, reguły, zasady będą obowiązywały również jutro, czy też ulegną modyfikacjom? A może w pewnych zakresach na stałe staną się niezmienne (autentycznie lub deklaratywnie), a w innych to właśnie zmiana będzie ich podstawową właściwością? „Zwłaszcza, iż kształtowanie własnego życia staje się przedsięwzięciem niedokończonym, otwartym projektem, stałym zadaniem i wezwaniem, nie tylko $\mathrm{w}$ fazie moratorium, ale i w dorosłej karierze. Taka sytuacja zmienia strukturę i funkcje tożsamości, czyniąc ją przedsięwzięciem refleksyjnym" (Krzychała, 2007b: 210).

\section{Młodzież i jej scenariusze własnego życia}

Konstruowanie przyszłości wiąże się bezpośrednio z tworzeniem scenariuszy własnego życia. Budowane wówczas wizje obejmują stawianie sobie celów wraz $\mathrm{z}$ ich realizacją oraz holistyczne wyobrażenia na temat swojej osoby. Do ich kreowania służą strategie: realistyczna (analiza sytuacji zewnętrznej i możliwości, którymi się dysponuje), autorytetu (bazowanie na opiniach, radach i wskazówkach innych osób), życzeniowa (fantazjowanie na temat przyszłości), przymusu (realizacja celów narzuconych przez inne osoby), oczekiwania (czekanie na to, co się wydarzy, co przyniesie los), carpe diem (korzystanie z uroków codzienności). Wyniki badań Celiny Timoszyk-Tomczak, prowadzonych wśród osób w wieku 18-26 lat (maturzystów, studentów i pracujących), pokazują, iż trzy pierwsze z nich są wyraźnie preferowane (Timoszyk-Tomczak, 2003).

Magdalena Piorunek wskazała następujące strategie projektowania przyszłości, będące $\mathrm{w}$ dużej mierze wynikiem preferowanych przez młodzież orientacji edukacyjnych i zawodowych: kondensacji („zawężania pola wyborów”), addytywną („układania puzzli”), stochastyczną („wyboru na chybił trafił” albo „zdania się na innych"), aktualistyczne w dwóch wariantach, czyli optymistycznym temporyzacji („przyjdzie czas, będzie rada”) i pesymistycznym - pasywną („nie widzę dla siebie perspektyw”), asekuracyjną („lepszy wróbel w garści”), dokonując na podstawie badań longitudinalnych wyłonienia trzech grup: osób aktyw-

\footnotetext{
${ }^{8}$ Plany na przyszłość są typowe i przewidywalne.
} 
nych $\mathrm{w}$ zakresie planowania własnego życia, które pomyślnie realizują powzięte postanowienia, osób w większym zakresie pasywnych życiowo, które jednak charakteryzuje subiektywnie pojęty sukces w realizacji postanowień, osób z dominacją nastawienia pasywnego, które w następstwie niepowodzeń egzaminacyjnych nie dostały się na studia i zostały zmuszone do modyfikacji drogi edukacyjnej (Piorunek, 2004: 69 i n).

Badania realizowane przez Sławomira Krzychałę w 2002 roku, w ramach których rekonstruował on projekty własnego życia młodzieży (uczniów trzecich klas szkół średnich - liceów, techników, szkół zawodowych), wykazały znaczną różnorodność tej grupy. Autor wyróżnił dwa poziomy projektu życia: komunikatywny „analiza pól semantycznych wypowiedzi młodzieży” i koniunktywny „refleksyjność socjobiograficzna, habitus organizacji własnego życia, sposób myślenia o własnej egzystencji, styl praktycznego radzenia sobie z codziennością", a w ich ramach odpowiednio: typy narracji planów życiowych (mieszczańskie, prowincjonalne, familijne, edukacyjne, zawieszenie planów) i typy refleksyjności (wygaszona, dyfuzyjna, przejęta, interakcyjna, strategiczna) (Krzychała, 2007a).

W projektach życia młodych ludzi zaobserwować można tendencję do przejścia z pierwszej racjonalno-strategicznej nowoczesności do jej drugiej, refleksywno-zindywidualizowanej fazy, tyle tylko, że to przejście nie dotyczy wszystkich w tym samym stopniu, nie zawiesza „nowoczesnej” logiki prowadzenia życia i dokonuje się bardziej 'subtelnie'. Refleksyjne, zindywidualizowane strategie organizacji życia współwystępują, a nawet mieszają się z przejmowanymi kolektywnymi (środowiskowymi) wzorami orientacji społeczno-biograficznej. (Krzychała, 2007a)

Główne elementy koncepcji własnego życia, to z kolei, zgodnie z modelem zaproponowanym przez Marię Czerwińską-Jasiewicz, dla której główną inspiracją były poglądy Jeana Piageta oraz Adama Niemczyńskiego:

- styl życia preferowany (czyli taki, który człowiekowi najbardziej odpowiada i jest bezpośrednio związany z jego potrzebami, cenionymi wartościami, światopoglądem, celami życiowymi, cechami indywidualnymi itd.) i realizowany (który może być w mniejszym lub większym stopniu zgodny z preferowanym, zależy bowiem od innych ludzi i warunków społecznych);

- cele życiowe (przyszłe stany rzeczy, mające dla jednostki znaczną wartość i siłę motywacyjną, dąży ona do nich poprzez działanie);

- plany życiowe (sposoby realizacji celów);

- decyzje życiowe (wybór jednej z wielu możliwych opcji).

$\mathrm{W}$ procesie tworzenia koncepcji własnego życia przez młodzież istotną rolę odgrywają następujące czynniki: system wartości ${ }^{9}$, czynniki społeczne (sytuacja

${ }^{9}$ Współczesne społeczeństwo jest złożone, niejednorodne, heterogeniczne (w kontekście i relacji, i reakcji, i instytucji, i możliwości). Obok zdezorientowanych młodych ludzi żyją ci, którzy energicznie 
kraju, sytuacja rodzinna, sytuacja szkolna) ${ }^{10}$, poziom rozwoju ogólnego (myślenia, osobowości, systemu wartości i światopoglądu, rozwoju społecznego) ${ }^{11}$, cechy indywidualne (inteligencja ogólna i zdolności specjalne; zainteresowania; cechy osobowości; cechy temperamentalne) ${ }^{12}$. Mogą one „znacząco wpływać zarówno na preferowanie i realizację stylu (modelu) życia, jak i na treść oraz sposób realizacji celów i planów życiowych, a także na treść i strategie podejmowania decyzji życiowych" (Czerwińska-Jasiewicz, 2015: 149-178). Zgodnie z wynikami badań prowadzonych przez Marię Czerwińską-Jasiewicz przez przeszło 15 lat wśród młodzieży w wieku 14-19 lat, większość młodych ludzi preferuje podobne style życia (mają więc one charakter uniwersalny); większość ma cele życiowe oraz formułuje cele życiowe zarówno krótkoterminowe, długoterminowe, jak i na całe życie, a dotyczą one kształcenia, pracy i rodziny; większość formułuje plany życiowe zarówno na krótkie okresy czasowe, jak i na dłuższe (10 lat), a odnoszą się one do dalszej edukacji, przyszłego zawodu, pracy i rodziny; istotną podstawę preferowania danych stylów życia i określania celów życiowych stanowią wartości; pewność decyzji życiowych młodzieży jest duża, natomiast ich autonomiczność przedstawia się różnie - w zależności od wieku (Czerwińska-Jasiewicz, 2015: 174-177). Wyniki badań prowadzonych przez Kingę Dziwańską wskazują również, że młodzi ludzie (w wieku 15-18 lat) charakteryzują się znacznie rozwiniętą przyszłościową perspektywą czasową. Formułują cele, konstruują plany „na dłuższe okresy czasowe oraz na całe życie”, podporządkowując to wartościom, myślą o przyszłości i postrzegają ją w racjonalny sposób (Dziwańska, 2011). Z kolei na podstawie badań powadzonych wśród studentów pedagogiki Uniwersytetu Jana Kochanowskiego Małgorzata Wolska-Długosz sformułowała wniosek, iż potrafią oni dobrze radzić sobie z planowaniem własnej przyszłości - począwszy od decyzji odnoszących się do dalszej

szukają dla siebie miejsca w społecznej przestrzeni. I jedni, i drudzy stają przed koniecznością dokonania wyboru wartości, które są nierozerwalnie związane z egzystencją człowieka. „Cały urok świata wartości bierze się zapewne stąd, że nic z tego świata nie narzuca się nam przemocą. Niemniej dzięki wartościom czujemy niewyraźnie, że jeśli tego świata nie uznajemy, możemy ulec jakiejś przemocy” (Tischner, 2002: 482).

${ }^{10}$ Pojawienie się trudności, związanych z: sytuacją społeczno-ekonomiczną kraju - m.in. problem bezrobocia, ubóstwa, zjawisko prekariatu, zagrożenie marginalizacją, ryzyko wykluczenia, z sytuacją rodzinną - np. relacje, warunki życia, nastawienie rodziców do planów syna/córki i z sytuacją szkolną w tym dotychczasowy przebieg kariery szkolnej, bariery na drodze do edukacji (lub ich brak) wpływa zatem bezpośrednio na realizację szans życiowych młodzieży.

${ }^{11}$ Co jest związane m.in. z własną interpretacją świata, nadawaniem znaczeń poszczególnym jego elementom, przyjmowaniem/odrzucaniem idei.

${ }^{12}$ Powodują, iż np. poszczególne jednostki inaczej reagują na podobne sytuacje, inaczej się zachowują wobec wyzwań, inne kwestie akcentują w ramach podejmowania codziennych aktywności, jak i w kontekście działań perspektywicznych. Mają wpływ na poziom i kierunek osiągnięć jednostki, wpływają na formułowanie przez nią celów życiowych. 
nauki (czyli realizacji własnych aspiracji edukacyjnych), po decyzje dotyczące życia osobistego (zdecydowana większość respondentów zadeklarowała, iż po zakończeniu studiów chce się usamodzielnić ${ }^{13}$ ) i drogi zawodowej (Wolska-Długosz, 2013: 99-109). Na ile te wizje mają szansę się urzeczywistniać? „W świecie, który mknie do przodu i nie ma sterników, a przyszłość jest niepewna”, gdzie „najbardziej logiczna wydaje się strategia «zrób to sam»". Bo inni nie wiedzą jak, nie mają czym lub nie potrafią. Jakkolwiek daje ona możliwość samodzielnego decydowania o własnym życiu, obarcza też dużym poczuciem odpowiedzialności za własny los"15.

Młodzież, dążąc do samorealizacji, doświadcza różnych kategorii kryzysu. Nieobcy jest jej kryzys o charakterze zarówno wewnętrznym (tożsamość indywidualna i kulturowa), jak i zewnętrznym (postrzeganie świata, swojego w nim miejsca oraz relacji $\mathrm{z}$ innymi). Znajduje się w sytuacji trudnej i to podwójnie, to znaczy zmaga się z problemami rozwojowymi (naturalnymi dla okresu adolescencji) oraz ze specyfiką ponowoczesnej rzeczywistości. Zgodnie z wnioskami z badań nad młodzieżą, prowadzonych przez Ewę Wysocką, młode pokolenie charakteryzuje wyraźna ambiwalencja w zakresie realnych (jak jest), idealnych (jak powinno być) i preferowanych (jak chcę, by było) wizji własnej osoby. Wizje siebie odnalezione - realne koncentrują się na teraźniejszości, celach życiowych związanych z przetrwaniem i wartościach codziennych (a nie transgresyjnych). Wizje siebie „konstruowane” - deklaratywne, idealne to wyraźna przewaga orientacji produktywnej (aktywność, prospołeczność) nad nieproduktywną (bierność, egocentryzm). Natomiast wizje siebie „preferowane”, odniesione do wzorów osobowych w ujęciu Floriana Znanieckiego i Zygmunta Baumana, to koncentracja na hedoniście (człowieku zabawy), perfekcjoniście (człowieku pracy) oraz romantycznie interpretowanym włóczędze (samowykluczający się, funkcjonujący „na marginesie życia”). W ocenie świata, własnej osoby, możliwości kreowania życia i realnego działania dominuje syndrom „zło świata”, wzmacniany przez „zło

\footnotetext{
${ }^{13}$ Jednak obecnie w Polsce ponad 43,5\% młodych osób w wieku 25-34 lata mieszka z rodzicami (porównując np. w Danii - 1,4\%, w Norwegii - 4,1\%, w Szwecji - 4,3\%, w Niemczech - 16,8\%, w Grecji - 51,5\%, w Serbii - 54,0\%). Za: Wojciechowski, 2015: 18-19.

${ }^{14}$ Pewien paradoks polega na tym, iż z jednej strony młodzi ludzie czują się swobodnie w tej sytuacji, od dzieciństwa uczą się bowiem istnieć w takiej rzeczywistości, w której nie ma ostatecznych/ rozstrzygających prawd i odpowiedzi, biorą więc „sprawy w swoje ręce” (Melosik, 2015: 27), z drugiej zaś - potrzebują pewności co warunków ich potencjalnych działań, potrzebują drogowskazów, by móc rozstrzygać indywidualne dylematy, a także muszą mieć szanse na dokonywanie spokojnej refleksji.

${ }^{15}$ „Młodzi nie tylko mają problemy z wchodzeniem w dorosłość, lecz i dojrzewanie psychiczne jest coraz trudniejsze. I chociaż zanadto się nie uskarżają, wielu z nich nie radzi sobie z nadmiernymi wymaganiami społeczeństwa, z kulturową presją na osiąganie sukcesu, z nieczytelnością społecznych norm, brakiem zainteresowania ze strony dorosłych, osłabieniem więzi rodzinnych czy balastem problemów własnych rodziców". Szafraniec, 2011: 29-30.
} 
innych ludzi”. Krytycyzm wobec siebie nie jest natomiast wyraźnie widoczny (Wysocka, 2011: 23-32).

Wnioskować można zatem, że młodzież mało idealistycznie, za to wyraźnie realistycznie konstruuje wizję własnego życia, ograniczając ją do sfer prywatnych, w których ma poczucie kontroli i sprawstwa, odrzucając zaś możliwość zmiany świata, nie przejawia większego zaangażowania społecznego (...). Nie widzi tym samym wyraźnie powiązania między kształtem własnego życia a kształtem świata, w którym żyje - w sensie pozytywnym („moje zaangażowanie w zmianę świata służy polepszeniu jakości mojego życia”), natomiast można sądzić, iż występuje tu negatywna tendencja określająca charakter tegoż powiązania - ponieważ świat i inni ludzie są „źli”, uprawnionym jest działanie moralnie kontrowersyjne (manipulacja). (Wysocka, 2011: 23-32)

Te deficyty/problemy/trudności w obszarze kreowania tożsamości i wdrożenia projektowanych scenariuszy własnego życia przez młodych ludzi stanowią bardzo mocny i czytelny sygnał, są alarmem dla pedagogów i wszystkich uczestniczących (bezpośrednio lub pośrednio - na przykład poprzez podejmowane decyzje, wprowadzające pewne ustalenia czy też obligujące do konkretnych działań) w życiu młodzieży, by wyjść naprzeciw jej oczekiwaniom i dać szansę na samorelizację.

\section{Podsumowanie}

$\mathrm{Na}$ drodze do samorealizacji można spotkać wiele barier, o czym wspomniano wyżej, a one związane są z działaniem czynników zewnętrznych i wewnętrznych; z poziomem makro-, mezo- i mikrospołecznym. Sam sposób przeżywania młodości pozwala domniemywać, czy adolescent „poszukuje siebie” (czerpiąc satysfakcję z różnych obszarów codzienności, realizując jednocześnie charakterystyczne dla tego okresu zadania rozwojowe), czy też trwa w narzuconej mu rzeczywistości, nie zwracając uwagi ani na przywileje związane z tą fazą życia, ani na wymagania przez nią dyktowane (co oczywiście może być związane z jego swobodnym wyborem „tak chcę", ale również z - niezależnymi od niego - niekorzystnymi uwarunkowaniami „tak muszę”). Wyłonione w trakcie badań przez Małgorzatę Oleniacz trzy sposoby przeżywania młodości mogą stanowić egzemplifikację zaistnienia tego procesu $\mathrm{z}$ różnym natężeniem. Gdzie na jednym biegunie znajduje się młodość dziecinna (z dominacją cech dziecięcych, dużą zależnością od otoczenia, niewielkim zakresem odpowiedzialności, małą aktywnością intelektualną, a tym samym - wąskim zakresem zainteresowań, skoncentrowaniem na sobie), na drugim biegunie - młodość dorosła ( $\mathrm{z}$ dużą odpowiedzialnością, autonomią, akceptacją siebie i otoczenia, znaczną aktywnością, ale też nadmiarem obowiązków), a pomiędzy nimi młodość pełna (charakteryzująca się 
zapałem, energią, zaangażowaniem, nadzieją, refleksyjnością i odpowiedzialnością) (Oleniacz, 2005). Na ile współczesne młode pokolenie może zatem realizować siebie? Bardzo trudno jednoznacznie odpowiedzieć na to pytanie. Kategoria heterogeniczności jawi się tu jako dominująca. Jest bowiem młodzież osiągająca sukcesy (w różnych obszarach życia), ale jest też młodzież, która definiuje swoją sytuację jako rozczarowanie codziennością. Na pewno należy uczynić wszystko, by ta pierwsza grupa nadal mogła cieszyć się egzystencją, dążąc do samorealizacji, a ta druga - by miała w ogóle na nią szansę. Jest to niezwykle ważne, gdyż wiąże się bezpośrednio z możliwością wypełniania istoty zadań rozwojowych, mających znaczenie dla „tu i teraz” młodzieży (tożsamość, projektowanie scenariuszy własnego życia), jak i jej dalszego funkcjonowania (satysfakcjonującego wkraczania w dorosłość i urzeczywistniania wcześniej poczynionych planów).

\section{Literatura}

Bauman Z. (2006). Płynna nowoczesność. Kraków.

Czerwińska-Jasiewicz M. (2015). Psychologia rozwoju młodzieży w kontekście biegu ludzkiego życia. Warszawa.

Dekiel M., Ukalisz A., Wiak K. (2013). Poszukiwanie sensu życia przez studentów pochodzacych z różnych środowisk społecznych. [W:] Z.B. Gaś (red.). Młodzież zagubiona - młodzież poszukująca. Lublin.

Drwal R.Ł. (1993). Percepcja ważności i realizacji zadań rozwojowych przez dorastajacych. [W:] Z. Smoleńska (red.). Badania nad rozwojem w okresie dorastania. Warszawa.

Dziwańska K. (2011). Cele, plany życiowe oraz wartości młodzieży w kontekście rozwoju orientacji przyszłościowej w okresie dorastania. Radom.

Giddens A. (2010). Nowoczesność i tożsamość. Warszawa.

Górniewicz J. (1991) Wstęp. [W:] J. Górniewicz (red.). Studia nad problematyka samorealizacji. Toruń.

Górniewicz J., Rubacha K. (1993). Droga do samorealizacji, czyli w poszukiwaniu tożsamości. Toruń.

Jędrzejewski M. (2013). Subkultury a samorealizacja w perspektywie edukacji i socjalizacji młodzieży. Toruń.

Konieczna D. (2014) Analiza dyskursu. W poszukiwaniu tożsamości współczesnej młodzieży. Warszawa.

Krzychała S. (2007a). Projekty życia. Młodzież w perspektywie badań rekonstrukcyjnych. Wrocław. Krzychała S. (2007b). Ryzyko własnego życia. Indywidualizacja w późnej nowoczesności. Wrocław. Łukaszewski W. (1984). Szanse rozwoju osobowości. Warszawa.

Melosik Z. (2015). Pedagogika i tożsamość młodzieży w kulturze kontroli i rozproszenia. [W:] K. Segiet (red.). Młodzież $w$ dobie przemian społeczno-kulturowych. Poznań.

Oleniacz M. (2005). Przeżywanie młodości. Obraz fenomenu w badaniach biograficznych. Kraków.

Oleszkowicz A. (1995). Kryzys młodzieńczy - istota i przebieg. Na podstawie wybranych psychologicznych koncepcji rozwoju człowieka i badań empirycznych. Wrocław.

Oleś P., Sobol-Kwapińska M. (2014). Między natura a kultura, czyli o rozwoju osobowości. [W:] M. Święcicka (red.). Drogi rozwoju osobowości dzieci i młodzieży. Warszawa. 
Piorunek M. (2004). Projektowanie przyszłości edukacyjno-zawodowej w okresie adolescencji. Poznań.

Szafraniec K. (2011). Młodzi 2011. Warszawa.

Timoszyk-Tomczak C. (2003). Strategie konstruowania własnej przyszłości. Szczecin.

Tischner J. (2002). Myślenie według wartości. Kraków.

Tylutki D. (2014). Koncepcja szczęścia w logoterapii V.E. Frankla. [W:] Z.B. Gaś (red.). Młodzież w poszukiwaniu szczęścia: dokąd, po co, jak i z kim? Lublin.

Wojciechowska L. (2011). Dobrostan psychiczny adolescenta $w$ obliczu realizacji rozwojowych zadań społecznych. [W:] D. Borecka-Biernat (red.). Zaburzenia w zachowaniu dzieci i młodzieży w kontekście trudnych sytuacji szkolnych i pozaszkolnych. Kraków.

Wojciechowski R. (2015). Wieczne dzieci. „Przegląd” nr 34 (816).

Wolska-Długosz M. (2013). Projektowanie przyszłości przez studentów pedagogiki Uniwersytetu Jana Kochanowskiego. [W:] W. Danilewicz, M. Sobecki, T. Sosnowski (red.). Środowisko - zasoby profesjonalizacja. Pedagogika społeczna wobec zmian przestrzeni życia społecznego. Warszawa.

Wysocka E. (2011). Młodzież jako kategoria rozwojowa i społeczna - obszary zagrożeń i empirycznych analiz pokolenia transformacji. [W:] Z. Palak, M. Piątek, A. Róg, B. Zięba-Kołodziej (red.). Jakość życia w procesie rozwoju dzieci i młodzieży. Tarnobrzeg.

Zimbardo P.G. (2004). Psychologia i życie. Warszawa. 
